\title{
Polymorphisms in biotransformation and DNA repair genes, and survival on head and neck squamous cell carcinoma
}

\author{
Polimorfismos em genes de biotransformação e reparo de DNA, e sobrevivência em \\ carcinoma de células escamosas de cabeça e pescoço \\ Osmar Amorim Novais' ${ }^{1}$, Débora Diniz Bezerra'1, Ana Angélica Leal Barbosa' ${ }^{1}$ Cintia Rodrigues Marques², \\ Marcílio Ferreira Filho ${ }^{3}$, Fabrício Rios-Santos ${ }^{4}$, Thiago Magalhães da-Silva ${ }^{1}$
}

\begin{abstract}
Objective: This study analyzed the association between xenobiotic metabolism and DNA repair gene polymorphisms and overall survival (OS) and disease-free survival (DFS) in patients diagnosed with HNSCC in a Brazilian population. Methods: Retrospective study included 91 patients with a confirmed diagnosis of HNSCC. A total of 7 genes were analyzed: XRCC1, HOGG1, CYP1A1, GSTM1, GSTT1, GSTP1 and NAT2. Results: Regarding OS, the largest mean differences were observed comparing GSTT1 rs71748309 null and GSTT1 rs71748309 non-null genotypes ( $p=0.050)$. In the gene-gene interaction analysis, the higher difference to OS was observed to the combined genotypes of the GSTM1 rs4025935 and GSTT1 rs71748309 ( $p=0.286)$. Regarding DFS, the largest mean differences were observed comparing GSTT1 rs71748309 null and GSTT1 rs71748309 non-null genotypes $(p=0.060)$ and to the combined genotypes of the GSTM1 rs4025935 and GSTT1 rs71748309 ( $p=0.313$ ). Conclusion: None of the polymorphisms evaluated in xenobiotic metabolism or DNA repair genes were significantly associated with HNSCC survival in our population. Confirmation of these results in larger studies is required.
\end{abstract}

Keywords: : Squamous cell carcinoma of head and neck; Survival; Polymorphism, Genetic; DNA; Gene.

\footnotetext{
1. Universidade Estadual do Sudoeste da Bahia, Departamento de Ciências Biológicas - Jequié - Bahia - Brazil.

2. Universidade Federal da Bahia, Instituto Multidisciplinar em Saúde, campus Anísio Teixeira - Vitória da Conquista - Bahia - Brazil.

3. Universidade Estadual de Santa Cruz, Departamento de Ciências da Saúde - Ilhéus - Bahia - Brazil.

4. Universidade Federal do Mato Grosso, Laboratório de Fisiologia, Faculdade de Medicina - Cuiabá - Mato Grosso - Brazil.
}

Financial support: none to declare.

Conflicts of interest: The authors declare no conflict of interest relevant to this manuscript.

Correspondence author: Osmar Amorim Novais.

E-mail: ozamorim@hotmail.com 


\section{RESUMO}

Objetivo: Este estudo analisou a associação entre o metabolismo xenobiótico e os polimorfismos do gene de reparo do DNA, e a sobrevivência geral (SG) e a sobrevivência livre de doença (SLD) em pacientes com diagnóstico de CECP em uma população brasileira. Métodos: Estudo retrospectivo que incluiu 91 pacientes com diagnóstico confirmado de CECP. Um total de 7 genes foram analisados: XRCC1, HOGG1, CYP1A1, GSTM1, GSTT1, GSTP1 e NAT2. Resultados: Em relação ao OS, as maiores diferenças médias foram observadas comparando os genótipos GST11 rs71748309 nulo e GST11 rs71748309 não nulo $(p=0,050)$. Na análise da interação gene-gene, a maior diferença para OS foi observada para os genótipos combinados de GSTM1 rs4025935 e GSTT1 rs71748309 ( $p=0,286)$. Em relação ao DFS, as maiores diferenças médias foram observadas comparando os genótipos GST11 rs71748309 nulo e GST11 rs71748309 não nulo ( $p=0,060)$ e os genótipos combinados do GSTM1 rs4025935 e GST11 rs71748309 ( $p=0,313$ ). Conclusão: Nenhum dos polimorfismos avaliados no metabolismo xenobiótico ou genes de reparo de DNA foram significativamente associados com a sobrevivência do CECP em nossa população. É necessária a confirmação desses resultados em estudos maiores.

Descritores: Carcinoma espinocelular de cabeça e pescoço; Sobrevivência; Polimorfismo Genético; DNA; Gene.

\section{INTRODUCTION}

Head and neck squamous cell carcinoma (HNSCC) is the sixth most incident cancer worldwide. ${ }^{1}$ Despite recent advances in prevention, detection, and diagnosis, the 5-year overall survival rate for HNSCC patients is among the lowest among the major malignancies. ${ }^{2}$ Several studies have analyzed the role of polymorphic variants in different survival outcomes in HNSCC. Polymorphisms in X-ray repair enzyme by crosscomplementation (XRCC1) and human 8-oxoguanine glycosylase 1 (HOGG1) genes, involved in the DNA repair pathway, and polymorphisms in N-acetyltransferase 2 (NAT2), glutathione S-transferase (GSTs) and cytochrome P450 1A1 (CYP1A1) genes, which are related xenobiotic metabolism pathways, are some examples of genetic factors studied in relationship to HNSCC survival. ${ }^{3-8}$ The results suggest that variability on patients survival can be explained, at least in part, by polymorphisms in genes encoding enzymes involved in these biological pathways., 2,-13 However, studies investigating the influence of polymorphisms on DNA repair and xenobiotic metabolism genes on HNSCC survival are still scarce for populations of developing countries. Thus, the aim of this study was to evaluate the impact of polymorphisms in biotransformation and DNA repair genes on overall survival (OS) and disease-free survival (DFS) in patients diagnosed with this type of carcinoma in a highly mixed population of northeastern Brazil.

\section{METHODS}

\section{Recruitment of volunteers}

The volunteers were recruited at the High Complexity in Oncology Center of the Santa Casa of Itabuna (CACON) and the Oncology Clinic of Ilhéus (CLIONI) between 2008 and 2009. 91 individuals, being 80 males, with a diagnosis of squamous cell carcinoma confirmed by anatomopathological examination were enrolled. All individuals signed the consent form approved by the Institutional Ethics Committee of the State University of Santa Cruz - UESC (Protocol Number: 134/2007). From each volunteer, three milliliters of peripheral blood were obtained that was later used in the extraction of genomic DNA. ${ }^{14}$

\section{Genotype tests}

\section{PCR-RFLP genotyping}

Polymorphisms for the XRCC1 rs25487 (Arg399GIn), HOGG1 rs1052133 (Ser326Cys), CYP1A1 rs1048943 and GSTP1 rs1695 (/le105Val) genes were analyzed using the polymerase chain reaction (PCR) followed by restriction fragment length polymorphism (RFLP). For the polymorphism of the XRCC1 gene the PCR product was digested by the restriction enzyme Mspl. For the polymorphism of the HOGG1 gene the PCR product was digested by restriction enzyme Mbol. ${ }^{15}$ For the Mspl polymorphism of the CYP1A1 gene the PCR product was digested by restriction enzyme Mspl, generating a single band of 343bp for the wild-type allele and two bands (one of 134bp and one of 209bp) for the mutant allele. For the Bsmal polymorphism of the GSTP1 gene the PCR product was digested by the restriction enzyme Mbol. ${ }^{16}$

\section{NAT2 gene sequencing and determination of acetylation profiles}

The polymorphisms of the NAT2 gene were genotyped by automated sequencing. Fourteen single nucleotide polymorphisms (SNPs) were analyzed: C190T, G191A, C282T, T341C, G363A, A411T, A434C, C481T, G499A, G590A, C759T, A803G, G857A and A845C. The PCR product (1141 bp) was sequenced on ABI3500 equipment (Applied Biosystems, Foster City, CA, USA), with the same PCR primers and 
additionally with two internal primers for total coverage of the fragment. ${ }^{15}$ The presence of the wild-type allele (absence of NAT2 polymorphisms) defined the rapid and intermediate phenotype and its absence, the slow phenotype.

\section{Detection of complete deletion polymorphism for GSTM1 and GSTT1 genes}

The GSTM1 and GSTT1 genes were amplified in a multiplex PCR, using the $\beta$-globin gene as the internal control of the reaction. The null genotypes for GSTM1 rs4025935 and GSTT1 rs71748309 were identified by the absence of 215 and $480 \mathrm{bp}$ amplification products, respectively. ${ }^{14}$

\section{Gene-gene interaction analysis}

Genotype-genotype and genotype-phenotype interactions of the analyzed genes were performed. These interactions were considered to genes that participate in complementary biological pathway. Because of the reduced sample size, the genotypegenotype and genotype-phenotype combinations were dichotomized. The index group (higher risk) was formed by the combination of genotypes and phenotypes potentially associated with the highest risk of death in our population and the reference group by the sum of all the others genotype classes for these markers. For instance, in the combination of the GSTM1 and GSTT1 genes, the index group consisted of the combined GSTM1 rs4025935 null and GST11 rs71748309 non-null genotypes, and the reference group was composed of the other genotype classes (GSTM1 rs4025935 null and GSTT1 rs71748309 null, GSTM1 rs4025935 non-null and GST11 rs71748309 non-null, GSTM1 rs4025935 non-null and GSTT1 rs71748309 null).

\section{Measures of survival}

Medical records of the patients participating in the study were used. Information regarding the date of diagnosis of the disease, the first day of the first treatment performed the date of death from any cause and the date of tumor recurrence were obtained. OS was defined as the interval between the first day, of the first treatment performed, and the date of death from any cause. DFS was measured as the interval between the first day of the first treatment performed and date of death from any cause or the date of tumor recurrence. Some individuals were censored due to non-occurrence of events. Censorship included patients who were alive up to the date of the last clinical evaluation recorded on medical records or until December 31, 2014, in order to guarantee a minimum follow-up of 5 years for all patients enrolled in the study.

\section{Statistical analysis}

OS and DFS probabilities were estimated using the Kaplan-Meier method. The log-rank test was applied to evaluate the statistical significance of the differences between the survival curves with the respective 95\% confidence intervals, according to the variables analyzed. All analyzes were conducted in the statistical package SPSS version 23.0 (SPSS, Chicago, IL, USA).

\section{RESULTS}

The study population consisted of 91 patients diagnosed with HNSCC. In the analyzed period, 65 patients were alive and 12 of them had tumor recurrence. Of the total population studied, the mean age was 59 years (range 30 to 88 years), $87.9 \%$ were males, $86.8 \%$ were self-declared non-whites, $94.5 \%$ declared themselves smokers, $74.7 \%$ were always alcoholics, $86.9 \%$ had low level of schooling, and $91.1 \%$ presented tumor in advanced stage. The distribution of the primary tumor site was oral cavity (24.1\%), the oropharynx (34.1\%), the hypopharynx (7.7\%), and the larynx (34.1\%). The mean follow-up time was 28.1 months (SD=25.8; range 1 to 95 months). The mean time between diagnosis and initiation of treatment was 3.1 months ( $S D=9.6$ months). The percentage of general deaths was $28.5 \%$ and the recurrence rate was $43.9 \%$. The OS overall mean was 64.1 months (95\% Cl: 54.4 months-73.8 months). The DFS overall mean was 63 months ( $95 \%$ Cl: 53 months-73 months). The 5-year OS rate was $67.6 \%$ and the 5 -year DFS rate was $66.6 \%$ (Table 1).

The mean OS and DFS times, according to the analyzed genotypes, are shown in Table 2 . With regard to OS the most remarkable differences, although not significant ( $p=0.050)$, was observed comparing GSTT1 genotypes, with GSTT1 rs71748309 null individuals presenting a mean OS of 33.3 months (95\% Cl: 13.4 months-53.2 months) while for GSTT1 rs71748309 non-null the mean OS was 66.7 months (95\% Cl: 56.7 months-76.7 months) (Figure 1A). Regarding DFS, the larger difference was observed for GSTT1 genotypes, with GSTT1 rs71748309 null individuals presenting a mean DFS of 33.3 months (95\% Cl: 13.4 months-53.2 months), whereas in those with GSTI1 rs71748309 non-null the mean DFS was 65.5 months $(95 \% \mathrm{Cl}$ : 55.2 months-75.9 months) (Figure 1B). Although considerable, the observed differences were not statistically significant $(p=0.060)$.

The mean OS and DFS times, according to gene-gene interactions are shown in Table 3. To OS the higher observed difference, although not significant $(p=0.286)$, was verified for the combination of GSTM1 and GSTT1 genotypes, with GSTM1 rs4025935 null and GSTT1 rs71748309 non-null individuals presenting a mean OS value of 57.2 months (IC 95\%: 47.1 months-67.2 months), while individuals with other genotypic combinations had a mean OS of 60.2 months (95\% Cl: 47.6 months-72.7 months) (Figure 1C). Regarding DFS, the most marked differences were for the combination of GSTM1 and GSTT1 genotypes, with GSTM1 rs4025935 null and GSTT1 rs71748309 non-null individuals presenting a mean DFS value of 51.7 months (IC 95 \%: 42.5 months-60.8 months), while individuals with other genotypic combinations had a mean DFS of 59.5 months $(95 \%$ Cl: 46.8 months-72.3 months) (Figure 1D). Although considerable, again the observed differences were not statistically significant $(p=0.313)$. 
Table 1. Characteristics of patients diagnosed with HNSCC.

\begin{tabular}{|c|c|}
\hline Characteristics & $\mathbf{N}(\%)$ \\
\hline \multicolumn{2}{|l|}{ Sex } \\
\hline Male & $80(87.9 \%)$ \\
\hline Female & $11(12.1 \%)$ \\
\hline Age, mean (SD) & 59 years $(11.6 \%)$ \\
\hline \multicolumn{2}{|l|}{ Color skin } \\
\hline White & $12(13.2 \%)$ \\
\hline Non-white & $79(86.8 \%)$ \\
\hline \multicolumn{2}{|l|}{ Smoker } \\
\hline Always & $86(94.5 \%)$ \\
\hline Never & $5(5.5 \%)$ \\
\hline \multicolumn{2}{|l|}{ Alcoholic } \\
\hline Always & $68(74.7 \%)$ \\
\hline Never & $23(25.3 \%)$ \\
\hline \multicolumn{2}{|l|}{ Education } \\
\hline Illiterate & $15(16.5 \%)$ \\
\hline Subscribe name only & $20(22 \%)$ \\
\hline Literate & $12(13.2 \%)$ \\
\hline Incomplete Elementary School & $29(31.9 \%)$ \\
\hline Complete Elementary School & $3(3.3 \%)$ \\
\hline Incomplete High School & $1(1.1 \%)$ \\
\hline Complete High School & $7(7.6 \%)$ \\
\hline Incomplete College & $2(2.2 \%)$ \\
\hline Complete College & $2(2.2 \%)$ \\
\hline \multicolumn{2}{|l|}{ Stage of tumora } \\
\hline I & $3(3.8 \%)$ \\
\hline II & $4(5.1 \%)$ \\
\hline III & $12(15.2 \%)$ \\
\hline IV & $60(75.9 \%)$ \\
\hline \multicolumn{2}{|l|}{ Primary site of tumor } \\
\hline Oral cavity & $22(24.1 \%)$ \\
\hline Oropharynx & $31(34.1 \%)$ \\
\hline Hypopharynx & 7 (7.7\%) \\
\hline Larynx & $31(34.1 \%)$ \\
\hline Follow-up time, mean (SD) & 28.1 months (25.8) \\
\hline Time between diagnosis and treatment, mean (SD) & 3.1 months (9.6) \\
\hline General deaths & $26(28.5 \%)$ \\
\hline Recurrence or death & $40(43.9 \%)$ \\
\hline Overall survival, mean (95\% CI) & 64.1 months (54.4-73.8) \\
\hline Disease-free survival, mean (95\% CI) & 63 months (53-73.8) \\
\hline 5 year overall survival & $67.6 \%$ \\
\hline 5 year disease-free survival & $66.6 \%$ \\
\hline
\end{tabular}

Some patients $(n=12)$ did not have the specified data.

\section{DISCUSSION}

In this study, we investigated the association of polymorphisms in biotransformation and DNA repair genes with the survival of patients diagnosed with HNSCC. Although no significant association was found in the present study, the impact of variants in these genes on HNSCC and other cancers survival was previously reported. ${ }^{17-20}$
Survival did not differ significantly for the GSTM1 rs4025935 null and GSTM1 rs4025935 non-null genotypes in 106 Chinese patients diagnosed with ovarian cancer and treated with chemotherapy. The GSTP1 rs1695 (lle105Val) Ile/Val (heterozygote) genotype showed no increased risk of death compared to the genotype GSTP1 rs1695 (Ile105Val) lle/lle (wild homozygote)..$^{19}$ In other studies was reported that polymorphism of the GSTP1 rs1695 
Table 2. Mean times of overall and disease-free survival according to the genotypes of patients diagnosed with HNSCC.

\begin{tabular}{|c|c|c|c|c|}
\hline $\begin{array}{l}\text { Genotypes and } \\
\text { phenotypes }\end{array}$ & $\begin{array}{l}\text { Mean overall survival } \\
(95 \% \mathrm{CI}) \text { (in months) }\end{array}$ & p value & $\begin{array}{l}\text { Mean disease free survival } \\
\quad(95 \% \mathrm{CI}) \text { (in months) }\end{array}$ & p value \\
\hline GSTM1 rs4025935 null & $55.8(46.2-65.4)$ & 0.457 & 50.5(41.8-59.3) & 0.482 \\
\hline $\begin{array}{l}\text { GSTM1 rs4025935 non- } \\
\text { null }\end{array}$ & $60.4(47.2-73.6)$ & & 59.7(46.2-73.1) & \\
\hline GSTT1 rs71748309 null & 33.3(13.4-53.2) & 0.050 & 33.3(13.4-53.2) & 0.060 \\
\hline $\begin{array}{l}\text { GSTT1 rs71748309 non- } \\
\text { null }\end{array}$ & $66.7(56.7-76.7)$ & & $65.5(55.2-75.9)$ & \\
\hline GSTP1 rs1695 (Ile105Val) & $61.7(48.8-74.6)$ & 0.901 & $60.3(47.1-73.5)$ & 0.850 \\
\hline \multicolumn{5}{|l|}{ Ile/Val or Val/Val } \\
\hline GSTP1 rs1695 (Ile105Val) & 64(50.3-77.7) & & 63.9(50.2-77.6) & \\
\hline \multicolumn{5}{|l|}{ Ile/Ile } \\
\hline $\begin{array}{l}\text { CYP1A1 rs1048943 TC or } \\
\text { CC }\end{array}$ & $56.8(43.2-70.3)$ & 0.542 & $54.9(40.7-69.1)$ & 0.511 \\
\hline CYP1A1 rs1048943 TT & $66.3(53.8-78.7)$ & & 65.7(53.1-78.3) & \\
\hline $\begin{array}{l}\text { XRCC1 rs25487 (Arg- } \\
\text { 399GIn) }\end{array}$ & $54.2(40.7-67.8)$ & 0.409 & $53.4(39.5-67.2)$ & 0.418 \\
\hline \multicolumn{5}{|l|}{ AA or GA } \\
\hline $\begin{array}{l}\text { XRCC1 rs25487 (Arg- } \\
\text { 399GIn) }\end{array}$ & $68.2(56.3-80.1)$ & & $66.6(53.8-79.4)$ & \\
\hline \multicolumn{5}{|l|}{ GG } \\
\hline HOGG1 rs1052133 & $62.5(45.5-79.4)$ & 0.947 & 61.2(43.7-78.7) & 0.964 \\
\hline \multicolumn{5}{|l|}{ (Ser326Cys) CG or GG } \\
\hline HOGG1 rs1052133 & $63.4(51.8-74.9)$ & & $62.3(50.4-74.1)$ & \\
\hline \multicolumn{5}{|l|}{ (Ser326Cys) CC } \\
\hline NAT2 slow & $65.8(51.1-80.6)$ & 0.797 & 63.6(47.7-79.4) & 0.961 \\
\hline $\begin{array}{l}\text { NAT2 rapid or } \\
\text { intermediate }\end{array}$ & $60.9(47.7-73.6)$ & & $59.9(46.5-73.2)$ & \\
\hline
\end{tabular}

(l/e105Val) was positively associated with second primary malignancies in patients treated to HNSCC ${ }^{21}$ and individuals with GSTT1 rs71748309 non-null genotype were more likely to die from HNSCC during the course of their disease. ${ }^{22}$

Silva et al. (2010), ${ }^{17}$ in turn, reported that the GSTT1 rs71748309 non-null genotype presented an inverse relationship between the risk of developing brain tumors and the survival rate in patients with malignant gliomas. In that study, this variant was associated with protection against cancer development and at the same time it was related to a lower OS. ${ }^{17}$ This same pattern was verified in our findings, since a higher OS rate was observed among the individuals with GSTT1 rs71748309 nonnull genotype, which was a risk factor for HNSCC in a previous case-control study carried out in the same population of present study. ${ }^{14}$

In the present study, no significant association was observed between the polymorphisms GSTM1 rs4025935 null and CYP1A1 rs1048943 Mspl and the OS of patients with HNSCC. A similar result was reported in a study conducted in the southeastern region of Brazil involving 153 patients diagnosed with HNSCC. ${ }^{23}$

Although in our population we have not observed any significant association of polymorphisms in XRCC1 rs25487 (Arg399GIn) and HOGG1 rs1052133 (Ser326Cys) repair genes with OS or DFS in HNSCC, the influence of these genes on survival rates in HNSCC and other cancers has been reported elsewhere. In a study conducted in a population of the United States, for example, a strong relationship has been demonstrated between the expression of the enzyme $X R C C 1$ and the OS of patients diagnosed with head and neck cancer. Elevated XRCC1 enzyme expression was associated with lower survival, particularly in patients treated with chemotherapy. ${ }^{11}$ Patients with lung cancer from a North Indian population with XRCC1 rs25487 (Arg399GIn) AA (variant homozygote) genotype had an increase in OS compared to those with XRCC1 rs25487 (Arg399G/n), GG (wild homozygote), and XRCC1 rs25487 (Arg399GIn) GA (heterozygote) genotypes. ${ }^{24}$

Other studies enrolling large samples found that the variant allele A of XRCC1 rs25487 (Arg399GIn) was 


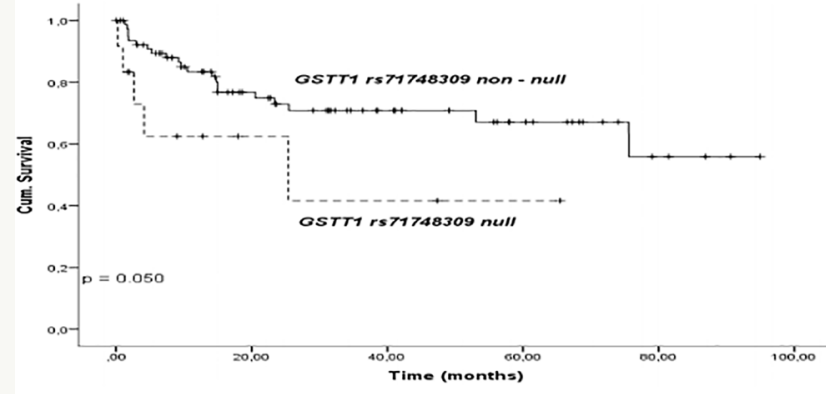

$1 \mathrm{~A}$

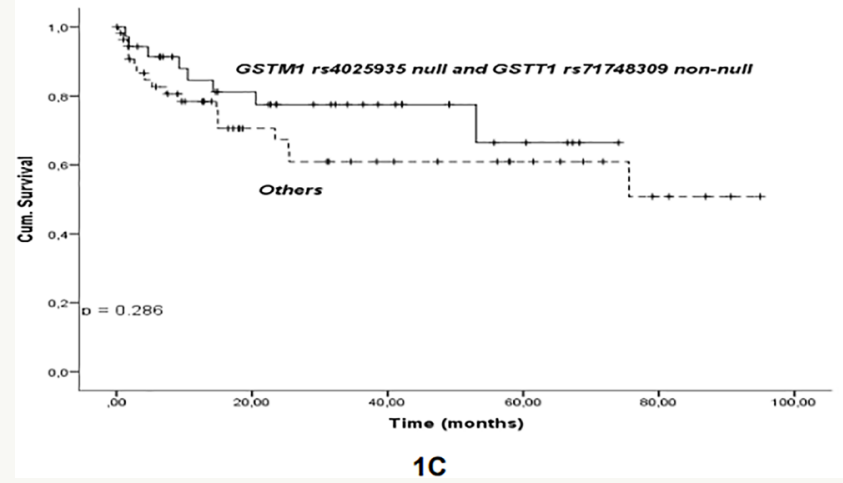

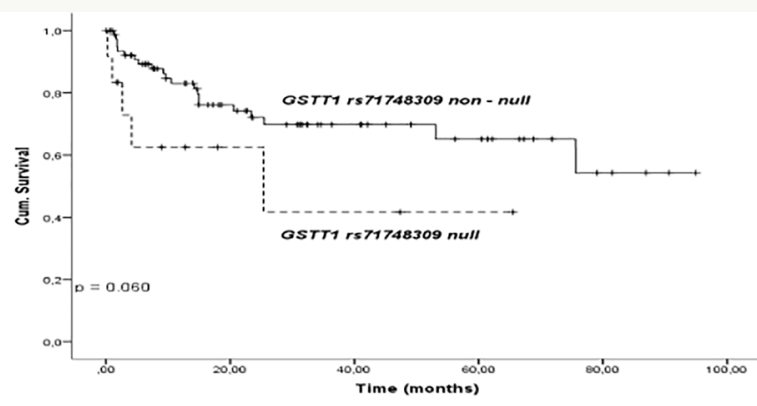

$1 B$

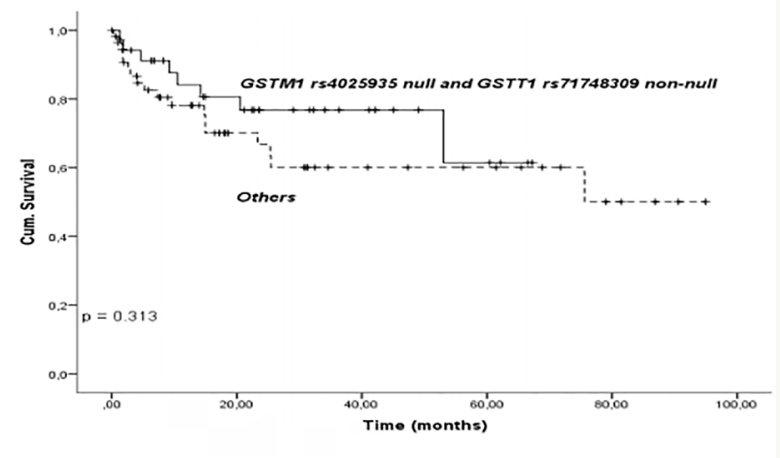

$1 \mathrm{D}$

Figure 1. Overall survival and disease-free survival curves. A. With regard to OS, were observed among GSTT1 genotypes, with GSTT1 rS71748309 null individuals presenting a mean OS value of 33.3 months ( $95 \% \mathrm{Cl}: 13.4$ months-53.2 months) while for those GSTT1 rs71748309 non-null the mean OS value was 66.7 months (95\% Cl: 56.7 months-76.7 months), $p=0.050 ; B$. GSTT1 genotypes, with GSTT1 rs71748309 null individuals presenting a mean DFS of 33.3 months (95\% Cl: 13.4 months-53.2 months), whereas in those with GSTT1 rs71748309 non-null the mean DFS was 65.5 months (95\% Cl: 55.2 months-75.9 months), $\mathrm{p}=0.060$; C. Regarding OS, the higher observed difference, although not significant, was verified for the combination of GSTM1 and GSTT1 genotypes, with GSTM1 rs4025935 null and GSTT1 rs71748309 non-null individuals presenting a mean OS value of 57.2 months IC 95 \%: 47.1 months-67.2 months), while individuals with other genotypic combinations had a mean OS of 60.2 months (95\% Cl: 47.6 months - 72.7 months), $p=0.286$; D. Regarding DFS, the most marked differences were for the combination of GSTM1 and GSTT1genotypes, with GSTM1 rs4025935 null and GSTT1 rs71748309 non-null individuals presenting a mean DFS value of 51.7 months (95\% Cl: 42.5 months-60.8 months), while individuals with other genotypic combinations had a mean DFS of 59.5 months ( $95 \%$ Cl: 46.8 months-72.3 months), p=0.313. Although considerable, again the observed differences were not statistically significant.

Table 3. Mean times of overall and disease-free survival according to gene-gene interactions of patients diagnosed with HNSCC.

\begin{tabular}{|c|c|c|c|c|}
\hline Genotypes and phenotypes & $\begin{array}{l}\text { Mean overall survival }(95 \% \mathrm{Cl}) \\
\text { (in months) }\end{array}$ & $\mathrm{p}$ value & $\begin{array}{l}\text { Mean disease free survival } \\
(95 \% \mathrm{Cl}) \text { (in months) }\end{array}$ & $p$ value \\
\hline $\begin{array}{l}\text { GSTM1 rs4025935 null and GSTT1 } \\
\text { rs71748309 non-null }\end{array}$ & $57.2(47.1-67.2)$ & 0.286 & $51.7(42.5-60.8)$ & 0.313 \\
\hline Other genotypic combinations & $60.2(47.6-72.7)$ & & $59.5(46.8-72.3)$ & \\
\hline $\begin{array}{l}\text { GSTM1 rs4025935 null and GSTP1 } \\
\text { rs1695 (Ile105Val) Ile/Val or Val/Val }\end{array}$ & $57.7(46.4-69)$ & 0.374 & $52.4(42.2-62.7)$ & 0.395 \\
\hline Other genotypic combinations & $60.9(49.2-72.6)$ & & $60.1(48.1-72)$ & \\
\hline $\begin{array}{l}\text { GSTT1 rs71748309 non-null and GSTP1 } \\
\text { rs1695 (Ile105Val) Ile/Val or Val/Val }\end{array}$ & $64.6(51-78.2)$ & 0.539 & 63(48.9-77) & 0.601 \\
\hline Other genotypic combinations & $60.8(48.1-73.5)$ & & $60.6(47.8-73.4)$ & \\
\hline $\begin{array}{l}\text { CYP1A1 rs1048943 TC or CC and NAT2 } \\
\text { slow }\end{array}$ & 73.2(55.9-90.6) & 0.373 & 73.2(55.9-90.6) & 0.475 \\
\hline Other genotypic/phenotypic combinations & $60.8(49.3-72.2)$ & & $59.8(48.2-71.5)$ & \\
\hline $\begin{array}{l}\text { XRCC1 rs25487 (Arg399GIn) AA or GA } \\
\text { and HOGG1 rs1052133 } \\
\text { (Ser326Cys) CG or GG }\end{array}$ & $41.9(25.3-58.5)$ & 0.806 & $39(20.8-57.2)$ & 0.678 \\
\hline Other genotypic combinations & $64.7(54.6-74.8)$ & & 63.9(53.6-74.3) & \\
\hline $\begin{array}{l}\text { GSTM1 rs4025935 null and CYP1A1 } \\
\text { rs1048943 TC or CC }\end{array}$ & $42.7(27.9-57.4)$ & 0.523 & $42.7(27.9-57.4)$ & 0.547 \\
\hline Other genotypic combinations & 65.5(55.1-75.9) & & $64.7(54.1-75.3)$ & \\
\hline $\begin{array}{l}\text { GST1 } 1 \text { rs71748309 non-null and CYP1A1 } \\
\text { rs1048943 TC or CC }\end{array}$ & $59.9(45.4-74.3)$ & 0.911 & $57.7(42.3-73.1)$ & 0.963 \\
\hline Other genotypic combinations & 63.3(51.1-75.5) & & $62.7(50.4-75.1)$ & \\
\hline $\begin{array}{l}\text { GSTP1 rs1695 (Ile105Val) lle/Val or } \\
\text { Val/Val and CYP1A1 rs1048943 TC or CC }\end{array}$ & $53.4(35.5-71.2)$ & 0.545 & 51(32.1-69.9) & 0.490 \\
\hline Other genotypic combinations & $65.7(55.1-76.4)$ & & $65.1(54.3-75.9)$ & \\
\hline
\end{tabular}


associated with improved OS or prolonged time to recurrence in patients with head and neck cancer. In contrast, a smaller study of 98 individuals genotyped for XRCC1 rs25487 (Arg399GIn) found no association with outcome. ${ }^{4}$ Costa et al. (2016), ${ }^{25}$ reported that polymorphisms in HOGG1 rs1052133 (Ser326Cys) were associated with shorter progression free disease in patients with advanced tumor stage of oropharyngeal squamous cell carcinoma. ${ }^{25}$ In turn, Chinese patients diagnosed with lung cancer presenting HOGG1 rs1052133 (Ser326Cys) CG (heterozygote) and HOGG1 rs1052133 (Ser326Cys) GG (variant homozygote) genotypes showed a reduced OS compared to those with the HOGG1 rs1052133 (Ser326Cys) CC (wild homozygote) genotype, especially in females. ${ }^{12}$

There are at least sixty known NAT2 polymorphisms grouped into slow, intermediate and rapid acetylator phenotypes that have been previously associated with cancer risk in other studies. ${ }^{18}$ In addition, the NAT2 gene can be an important prognostic factor for the survival of patients in other types of cancers. ${ }^{10}$ Previous analysis showed that NAT2 rapid acetylator phenotypes had a $19.7 \%$ increased 5-year OS rate compared to NAT2 slow acetylator in oropharyngeal and oral cavity cancer cases. ${ }^{18}$

\section{CONCLUSION}

In the present study, some outstanding differences for OS and DFS according to analyzed genetic variants were observed, although they were not statistically significant. The small sample size is an important limitation, resulting in part of the difficulties of performing a follow-up of cancer patients residing in the interior of Brazil based on search to secondary data deposited in systems that were not originally developed for research purposes. The results obtained in the present study should be confirmed in the future in larger and better-designed studies, in addition to meta-analysis studies, in order to clarify the true role of these variants on survival in the HNSCC.

\section{ACKNOWLEDGEMENTS}

This research involved the participation of the teams of the State University of Santa Cruz - UESC and the State University of Southwest of Bahia - UESB.

\section{REFERENCES}

1. Braakhuis BJM, Brakenhoff RH, Leemans CR. Treatment choice for locally advanced head and neck cancers on the basis of risk factors: biological risk factors. Ann Oncol. 2012 Sep;23(Suppl 10):x173-7.

2. Farnebo $L$, Stjernström $A$, Fredrikson $M$, Ansell $A$, Garvin S, Thunell LK. DNA repair genes XPC, XPD, XRCC1, and XRCC3 are associated with risk and survival of squamous cell carcinoma of the head and neck. DNA Repair (Amst). 2015 Jul;31:64-72.
3. Weiss JM, Goode EL, Ladiges WC, Ulrich CM. Polymorphic variation in HOGG1 and risk of cancer: a review of the functional and epidemiologic literature. Mol Carcinog. 2005 Mar;42(3):127-41.

4. Hopkins J, Cescon DW, Tse D, Bradbury P, Xu W, Ma C, et al. Genetic polymorphisms and head and neck cancer outcomes: a review. Cancer Epidemiol Biomarkers Prev. 2008;17(3):490-9.

5. Khlifi R, Chakroun A, Hamza-Chaffai A, Rebai A. Association of CYP1A1 and CYP2D6 gene polymorphisms with head and neck cancer in Tunisian patients. Mol Biol Rep. 2014;41(4):2591-600.

6. Choudhury JH, Singh SA, Kundu S, Choudhury B, Talukdar FR, Srivasta S, et al. Tobacco carcinogen-metabolizing genes CYP1A1, GSTM1, and GSTT1 polymorphisms and their interaction with tobacco exposure influence the risk of head and neck cancer in Northeast Indian population. Tumour Biol. 2015 Aug;36(8):5773-83.

7. Li F, Wang J, Chen M. Single nucleotide polymorphisms in DNA repair genes and the risk of laryngeal cancer: a meta-analysis. Biomed Pharmacother. 2016 Mar;78:92-100.

8. Feki-Tounsi M, Khlifi R, Louati I, Fourati M, Mhiri MN, Hamza-Chaffai, et al. Polymorphisms in XRCC1, ERCC2, and ERCC3 DNA repair genes, CYP1A1 xenobiotic metabolism gene, and tobacco are associated with bladder cancer susceptibility in Tunisian population. Environ Sci Pollut Res Int. 2017 Oct;24(22):22476-84.

9. Ekhart C, Rodenhuis S, Smits PHM, Beijnen JH, Huitema ADR. An overview of the relations between polymorphisms in drug metabolising enzymes and drug transporters and survival after cancer drug treatment. Cancer Treat Rev. 2009 Feb;35(1):18-31.

10. Osian G, Procopciuc L, Vlad L, lancu C, Cristea PG, Mocan T, et al. NAT2 polymorphisms and sporadic colorectal cancer survival. J Gastrointestin Liver Dis. 2010 Nov; 19(4):361-8.

11. Ang $M K$, Patel $M R$, Yin $X Y$, Sundaram $S$, Fritchie $K$, Zhao N, et al. High XRCC1 protein expression is associated with poorer survival in patients with head and neck squamous cell carcinoma. Clin Cancer Res. 2011 Oct;17(20):6542-52.

12. Su Y, Zhang $H, X u F$, Kong J, Yu H, Qian B. DNA repair gene polymorphisms in relation to nonsmall cell lung cancer survival. Cell Physiol Biochem. 2015;36:1419-29.

13. Pasqualetti F, Gonnelli A, Cantarella M, Delishaj D, Molinari A, Ortenzi V, et al. Association of glutathione S-transferase P-1 (GSTP-1) rs1695 polymorphism with overall survival in glioblastoma patients treated with combined radio-chemotherapy. Invest New Drugs. 2017 Apr;36(2):340-5. 
14. Silva TM, Marques CR, Marques Filho MF, Marques $A B$, Di Pietro G, Rios-Santos F. Association of the GSTT1 polymorphism in upper aerodigestive tract cancer with tobacco smoking. Genet Mol Res. 2014 Jan;13:528-37.

15. Marques CR, Silva TM, Albuquerque DM, Chaves MS, Marques Filho MF, Oliveira JS, et al. NAT2, XRCC1 and HOGG1 polymorphisms, cigarette smoking, alcohol consumption and risk of upper aerodigestive tract cancer. Anticancer Res. 2014 Jun;34(6):3217-24.

16. Harries LW, Stubbins MJ, Forman D, Howard GC, Wolf CR. Identification of genetic polymorphisms at the glutathione S-transferase $\mathrm{Pi}$ locus and association with susceptibility to bladder, testicular and prostate cancer. Carcinogenesis. 1997 Apr;18(4):641-4.

17. Silva MS, Carvalho M, Santos TQ, Bucco BM. Estudo do polimorfismo dos genes GSTT1 e GSTM1 em pacientes de gliomas malignos. Rev Ciênc Méd Biol. 2010;9:200-3.

18. TroyJD, Weissfeld JL, Diergaarde B, YoukAO, Buch SC, Romkes $\mathrm{M}$, et al. Polymorphisms in NAT2 and GSTP1 are associated with survival in oral and oropharyngeal cancer. Cancer Epidemiol. 2013 Aug;37(4):505-11.

19. Zhai XH, Huang J, Wu FX, Zhu DY, Wang AC. Impact of XRCC1, GSTP1, and GSTM1 polymorphisms on the survival of ovarian carcinoma patients treated with chemotherapy. Oncol Res Treat. 2016;39(7-8):440-6.
20. Jain $V$, Ratre $Y K$, Amle $D$, Mishra $P K$, Patra PK. Polymorphism of CYP1A1 gene variants rs4646903 and rs1048943 relation to the incidence of cervical cancer in Chhattisgarh. Environ Toxicol Pharmacol. 2017 Jun;52:188-92.

21. Zafereo ME, Sturgis EM, Aleem S, Chaung K, Wei Q, Li G. Glutathione S-transferase polymorphisms and risk of second primary malignancy after index squamous cell carcinoma of the head and neck. Cancer Prev Res (Phila). 2009 May;2(5):432-9.

22. Geisler SA, Olshan AF, Cai J, Weissler M, Smith J, Bell D. Glutathione S-transferase polymorphisms and survival from head and neck cancer. Head Neck. 2005 Jan;27(3):232-42.

23. Olivieri EHR, Silva SD, Mendonca FF, Urata YN, Vidal DO, Faria MA, et al. CYP1A2*1C, CYP2E1*5B, and GSTM1 polymorphisms are predictors of riskand poor outcome in head and neck squamous cell carcinoma patients. Oral Oncol. 2009 May;45(9):e73-9.

24. Singh A, Singh N, Behera D, Sharma S. Polymorphism in XRCC1 gene modulates survival and clinical outcomes of advanced North Indian lung cancer patients treated with platinumbased doublet chemotherapy. Med Oncol. 2017 Apr;34(4):64.

25. Costa EFD, Santos ES, Liutti VT, Leal F, Santos VCA, Rinck-Junior JA, et al. Association between polymorphisms in genes related to DNA baseexcision repair with risk and prognosis of oropharyngeal squamous cell carcinoma. J Cancer Res Clin Oncol. 2016 Sep;142(9):1917-26. 